\title{
THE HYSTERICAL MALE
}

new feminist theory 


\section{Culture'Texts}

Arthur and Marilouise Kroker General Editors

Culture texts is a series of creative explorations in theory, politics and culture at the fin-de-millenium. Thematically focussed around key theoretical debates in the postmodern condition, the CultureTexts series challenges received discourses in art, social and political theory, feminism, psychoanalysis, value inquiry, science and technology, the body, and critical aesthetics. Taken individually, contributions to $\mathrm{Cul}$ tureTexts represent the forward breaking-edge of postmodern theory and practice.

Titles

The Hysterical Male: new feminist theory

edited and introduced by Arthur and Marilouise Kroker

$$
\begin{aligned}
& \text { Seduction } \\
& \text { Jean Baudrillard }
\end{aligned}
$$

Panic Encyclopedia

Arthur Kroker, Marilouise Kroker and David Cook

Life After Postmodernism: Essays on Value and Culture edited and introduced by John Fekete

Body Invaders

edited and introduced by Arthur and Marilouise Kroker

The Postmodern Scene: Excremental Culture and Hyper-Aesthetics Arthur Kroker/David Cook 


\section{THE HYSTERICAL MALE new feminist theory}

edited and introduced by Arthur and Marilouise Kroker

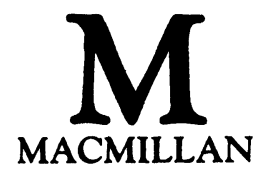


() New World Perspectives, Culture'Texts Series 1991

All rights reserved. No reproduction, copy or transmission of this publication may be made without written permission.

No paragraph of this publication may be reproduced, copied or transmitted save with written permission or in accordance with the provisions of the Copyright, Designs and Patents Act 1988 or under the terms of any licence permitting limited copying issued by the Copyright Licensing Agency, 22-4 Alfred Place, London WC1E 7DP.

Any person who does any unauthorized act in relation to this publication may be liable to criminal prosecution and civil claims for damages.

First published 1991

Published by

MACMILLAN EDUCATION LTD

Houndmills, Basingstoke, Hampshire RG21 2XS

and London

Companies and representatives

throughout the world

British Library Cataloguing in Publication Data

The Hysterical Male : new feminist theory.

1. Feminism

I. Kroker, Arthur 1945- II. Kroker, Marilouise 305.42

ISBN 978-1-349-12534-0 ISBN 978-1-349-12532-6 (eBook)

DOI 10.1007/978-1-349-12532-6 
On December 6, 1989, fourteen women were murdered at the Université de Montréal. "I want the women." "You're all feminists." That is what the twenty-five year old male dressed in hunting gear with a semiautomatic rifle in one hand and a hunting knife in the other shouted when he ordered the men to leave and the women to stay.

We dedicate this book to these fourteen women, murdered because they were thought to be feminists. 


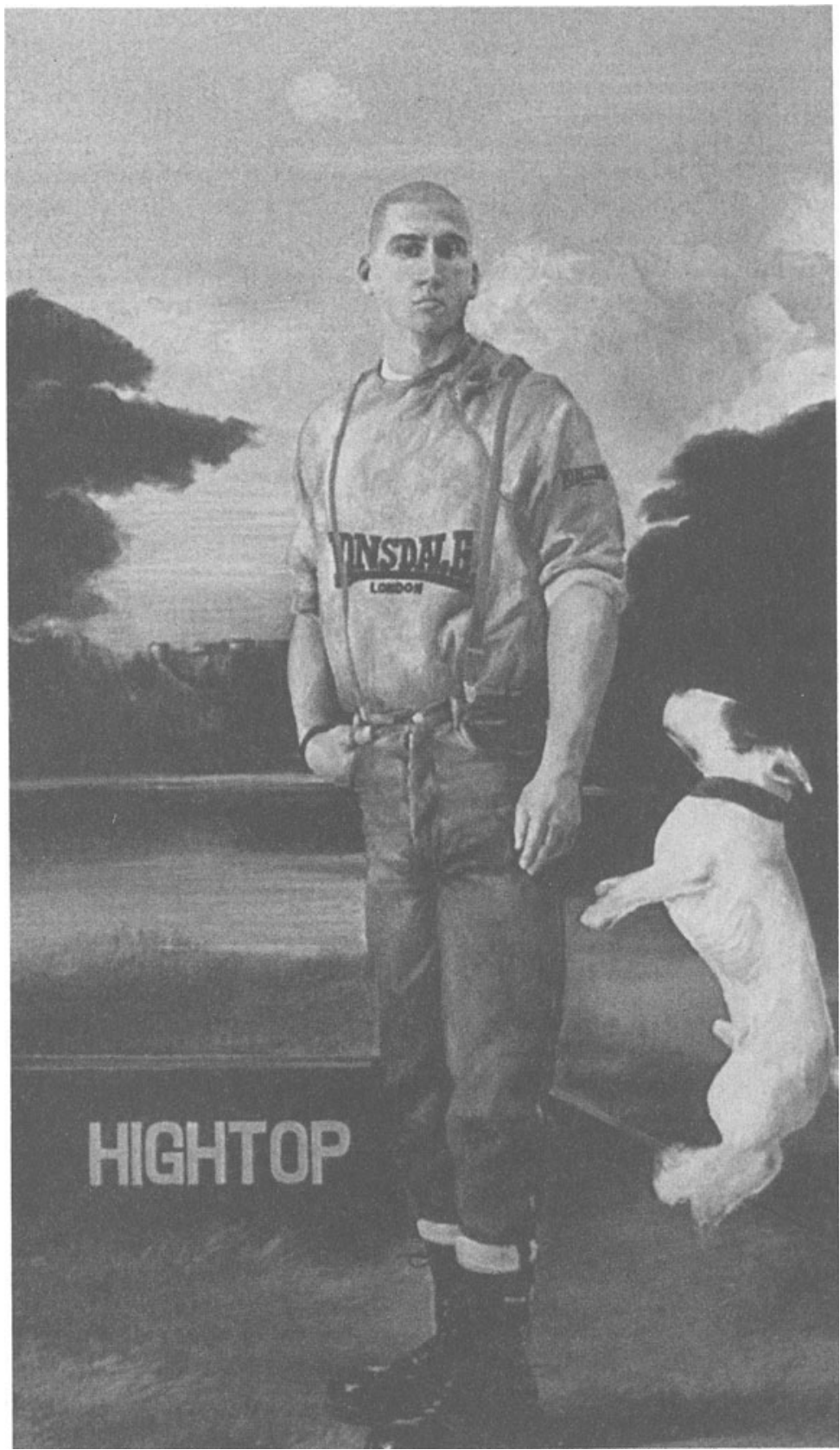

Attila Richard Lukacs, True North (detail) 


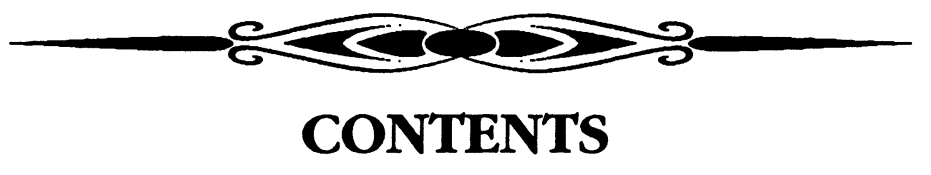

The Hysterical Male: new feminist theory ix Arthur and Marilouise Kroker

\section{Sacrificial Sex}

1 Three Sisters: Pure Virtue, Pure Sin and Pure Nonsense

Elke Town (photography by David Hlynsky)

2 Big Jugs

Jennifer Bloomer

3 A Ghost Story Avery Gordon

4 Behind Master Mind

Charles Noble

\section{Mirror of Seduction}

5 The Confession Mirror

Carole Spitzack

6 Blondes

Teresa Podlesney

7 Confessions of a Harlequin Reader: The Myth of Male Mothers Angela Miles

8 Yvonne Rainer's The Man Who Envied Women Peggy Phelan 


\section{Phallus of Malice}

9 Parading the Masculine

Chris Tysh

10 Feminist Ejaculations

Shannon Bell

11 The Fetish in Sex, Lies \& Videotape:

Whither the Phallus?

Berkeley Kaite

12 My First Confession

187

Stephen Pfohl

13 Simulations

188

Andrew Haase

\section{Daddy's No}

14 The Phallic Mother: Platonic Meta-physics

212 of Lacan's Imaginary

Lorraine Gauthier

15 Lacanian Psychoanalysis and Feminist Metatheory 235 Charles Levin

16 This is not a President: Baudrillard, Bush, 253 and Enchanted Simulation

Diane Rubenstein

Contributors

268

Acknowledgments

271 


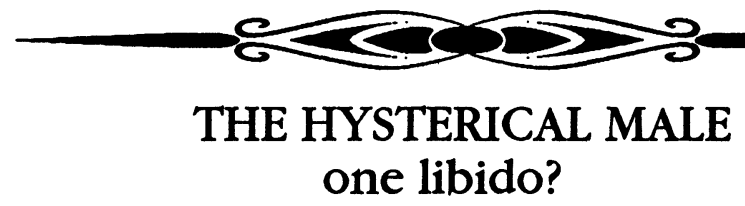

Arthur and Marilouise Kroker

The hysterical male, then, as a prelude to the seduction of one libido. If the image of the hysterical male can be so popular in cinema today (Sex, Lies EVideotape, Dead Ringers, Total Recall, Robocop), maybe that is because there is no longer a relationship between sex and power.

Power, fleeing its basis in sexuality generally and male subjectivity specifically, becomes now a viral power, a power which speaks only in the previously transgressive feminist language of absence, rupture, plurality, and the trace. A post-male power which leaves behind male subjectivity as a hysterical photographic negative of itself, and which disappropriates women of the privileged ontology of the Other.

Or is it just the reverse? Not the decoupling of sex and power, but a hyper-infusion of power by a male sex which, speaking now only in the fantasy language of one libido, seeks to hide the privileging of the phallocentric gaze by theorizing the disappearance of power into seduction.

The psychoanalytics of one libido, therefore, as one last playing-out of old male polyester sex theory, a big zero.

Or maybe it's neither. Not one libido theory nor its denial, but the production of neon libidos in the age of sacrificial sex, when sexuality too is both produced by power as a trompe l'oeil and then cancelled out. Sacrificial sex, therefore, as a time of the monstrous double, when all the sex differences are simulated and exterminated in a spiralling combinatorial of cynical signs. 


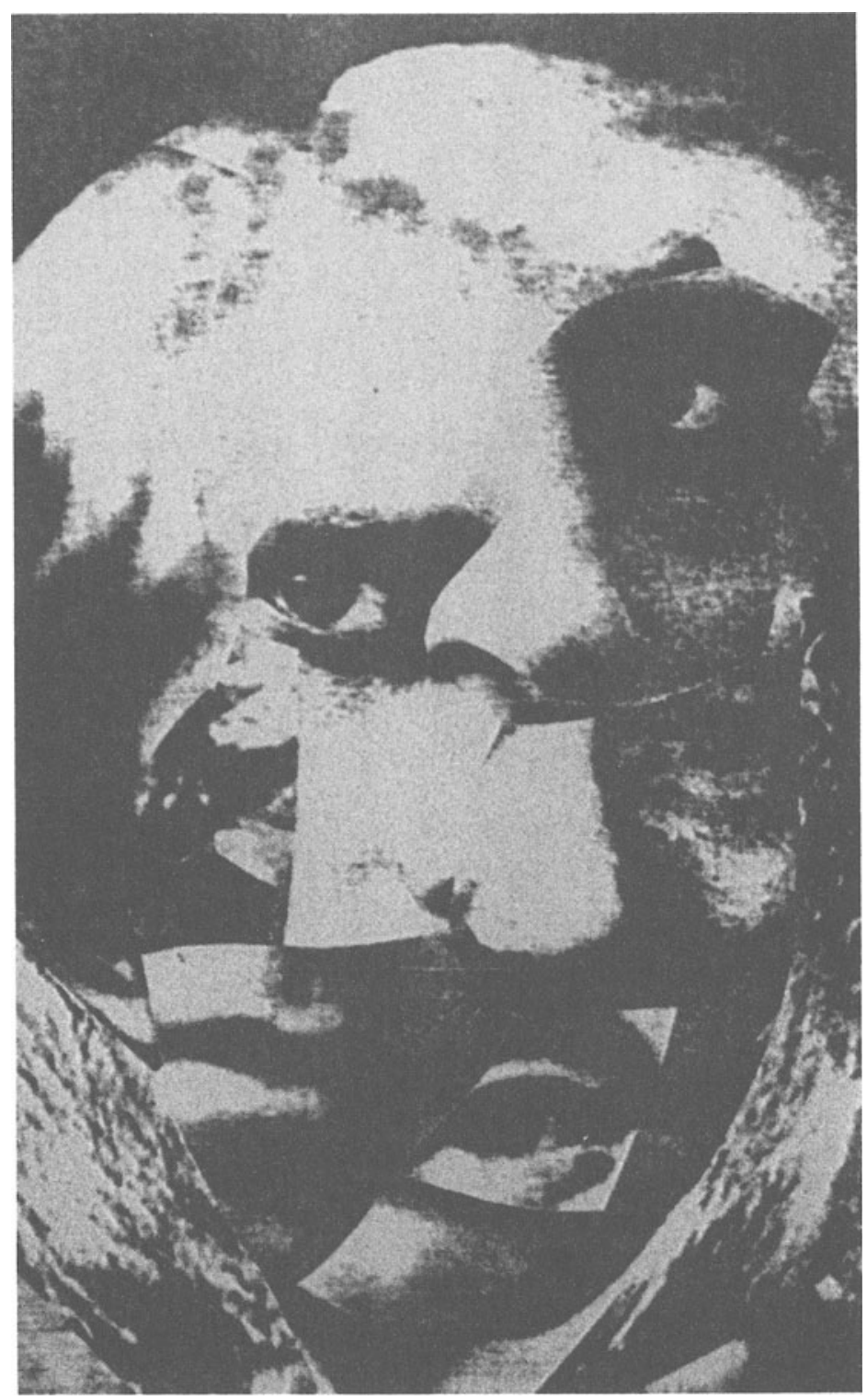

Marc de Guerre 


\section{The Penis as a Mutant Clitoris}

The key to decoding the psychoanalytics of the hysterical male at the end of the twentieth century is to read Freud's theory of seduction, his theory of the hysterical female written at the end of the nineteenth century, in reverse image.

Here, there is only one sex: the female sex. Freud got it all wrong. He insisted that female hysteria had its sexual origins in the teenage repression of the clitoris as an erotegenetic zone and the forced shifting of the sexual register from the clitoris (Freud's "masculine sexuality") to the vagina. Freud's victory sign was the repression of the eroticism of the clitoris, and the celebration of vaginal sex as the triumphant sign of the double exclusion of women from their own sex. The lost clitoris, then, as an eternally recurring sign of penis envy for the female hysteric living within the horizon of the Victorian sexual prohibition, and for the political fate of women of having to learn their own sex through that ideological interpellation of male power-the Freudian vagina.

But why not the opposite? Why not the penis now as a sign of the mutant clitoris, as a postmodern clitoris under the sign of abuse value? No longer the clitoris as a minimalist penis, but the postmodern penis as a runaway outlaw clit-like Pinnochio's nose?

Or is it both? The nineteenth century clitoris as a failed Freudian penis (with the vagina as a sign of repressed absence), and the twentieth century penis as a hyper-inflated clitoris (with Freud's one male sex as itself as fatal theory of sexual flatlining). Freud's penile theory made this big mistake. It never gave credence to the sexual fact that women can ejaculate, and that, consequently, the dialectic of the clitoris and the vagina was that of one sex, a female sex, moving through a pleasurable libidinal sexual economy of discharge and bodily memory.

The female hysteric, then, as a quintessential sign of the repression of masculine denial. Not so much the hysterical female, but the first of all the existentialists-Freud's Dora-who can report her condition as "nausea and disgust" because she is surrounded by all the repressed signs of denial of the hysterical male: the male hysteric who desperately needs discharge, but who can't discharge directly, and does so through the conversion of sexual lack into emotionally cathected ideas.

Or maybe it is something more. Not just male hysteria in relation to sexual lack, but as the emblematic sign of a more primordial lack in postmodern society. Maybe male hysteria-the hysteria of the mutant sex-expresses a more fundamental inversion: the inversion of space over memory, of the ideological order of the phallus over embodied history. Male sex, then, as the sovereignty of desire as lack over libidinal history, which is to say of spatialization over the body. An endless revenge-taking by the mutant sex against the body, against the pleasures of the clitoris. Indeed, if Virilio can write so eloquently now about the 


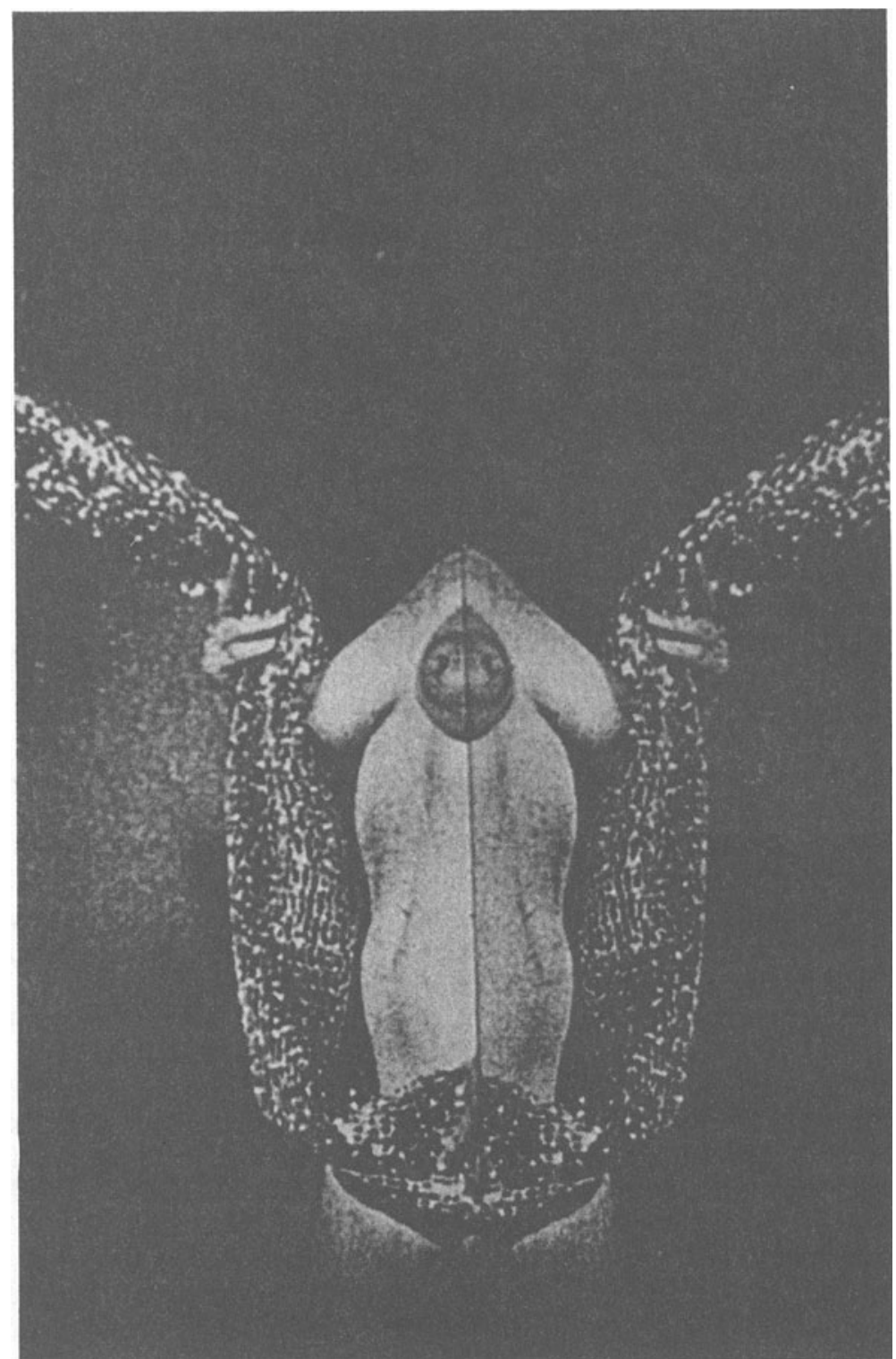

Photo: Marc de Guerre 
postmodern body as a "war machine", about, that is, the indefinite combination of speed and politics into a new form of "dromocracy", maybe that's because as a privileged participant in the mutant sex he can understand so well the dialectic of lack and deterrence. Male sexual discharge as also a kind of deferral of knowledge of absence which, first having its basis in the penis as a mutant clitoris, expands rapidly into a universal political logic of revenge-taking.

\section{The New Sacred Object}

Why is the image of the erect penis now privileged as a cathected object for political prohibition?

A new drive towards male puritanism in which the Madonna image does a gender flip? No longer woman as 'sacred vessel', but the erect penis as a probibited object of the gaze. A sacramentalized penis which can fall under a great visual prohibition because it is now the sacred object. Perhaps a last domain of innocence for anxious men, desperate about all of the gains made by movements for sexual liberation. And so, the erect penis is encoded with all the liturgical trappings of a sacred vessel: the ideological probibition of the gaze, an unseen object of veneration, an erectile domain of semiotic innocence. The erect penis, therefore, as a key agent in a new discourse of semio-sex which can be so fundamentalist in its cultural prohibitions because it screens out the reality of a culture which is all about a ruthless patriarchal politics of back to the penis. Political injunctions against images of the erect penis, therefore, as also about the repression of denial.

But, of course, the question remains: You can cover it up, but will it go away? If the erect penis can be so semiotically innocent, that is because a great political reversal is now taking place. The erect penis can acquire a cultural discourse of innocence in direct and intense relation to the new material reality of a penile power which, under the impact of a decaying neo-conservativism moving from the political to the cultural sphere, is all about predatory power against women and children. Is the new penis censorship just a camouflage, then, for a new fundamentalist cultural politics based on a new order of phallocentric domination: violence against women, the sexual abuse of children, a whole sexual politics based on the libidinal economy of abuse value? The new sexual censorship, therefore, recapitulates the historical traditions of puritanical movements: the cultural reality of a sacred object as a displaced sign for a material reality based on sexual abuse. Consequently, the discourse of the erect penis as a sacred object is central to the newly resurgent ideology of the hysterical male. 


\section{Crash Subjectivity}

The theorisations in this book are written under the sign of the failing penis as the emblematic mark of postmodern subjectivity. They originate in that shadowland where the real material penis disappears into the ideology of the phallus, and where the privileged figure of the masculine throws off its Freudian burden of repression, becoming what it always secretly coveted-fully hystericized subjectivity. That fateful point where the specular coherence of unitary male subjectivity shatters, and what remains is but the violent residues of the death of the old male cock. Crash male subjectivity, and crash male bodies too, as the hysterical sign of the fatal breakdown of the symbolic order of the unitary male subject.

The Hysterical Male: new feminist theory is a thematically focussed exploration of feminism in the 1990s. Initiated as a companion text to Body Invaders, The Hysterical Male traces out the logic of imminent reversibility in received patriarchal discourses in psychoanalysis, art, theory and culture. Here, under the sign of male hystericization, critical feminist theorists track the next stage of gender politics. From the theoretical fallout from Daddy's No (refusing the psychoanalytics of the Lacanian symbolic) and Phallus of Malice (where the image of the ejaculating woman substitutes for the disappearing penis) to the Mirror of Seduction (where women, too, are doubled in an endless regression of mirrored identities) and Sacrificial Sex (where feminism is encoded in a labyrinth of seductive images), The Hysterical Male nominates new feminist theory in light of the inverted world of the male hysteric. What results is an intense, provocative and creative theorisation of feminism under the failing sign of male hystericization-the death of the privileged ideology of the unitary male subject. 